\title{
Reconnaissance Geochemical Exploration in Kaiama, North Central, Nigeria
}

\author{
Alepa $\mathrm{VC}^{1}$, Bale $\mathrm{RB}^{1}$, Alimi $\mathrm{SA}^{1}$, Bonde $\mathrm{DS}^{2 *}$ \\ ${ }^{1}$ Department of Geology and Mineral Sciences, University of Ilorin, Ilorin, Nigeria \\ ${ }^{2}$ Department of Physics,Kebbi State University of Science and Technology, Alierol,Nigeria
}

DOI: $10.36348 /$ sjeat.2019.v04i11.003 $\quad$ | Received: 16.11.2019| Accepted: 23.11.2019 | Published: 28.11.2019

*Corresponding author: Bonde DS

\section{Abstract}

Reconnaissance exploration for ore mineralization in Kaiama and environ have been carried out using integrated geological mapping and geochemical survey of soils, stream sediments and exposure of pegmatite/quartz veins. This was done in order to define the ore forming elements distribution and recognising type and area of possible mineralization in Kaiama and environ.. Eighteen samples were collected and analyzed for major and trace elements by $\mathrm{x}$-ray fluorescence (XRF) and particle induced x-ray emission (PIXE) methods. Petrological description of thin sections of rocks was also carried out under the petrological microscope.The rocks underlying Kaiama consist of amphibolites, mica schists and granites along with fracture controlled mostly sheared mineralised pegmatite and quartz veins The fractured filled veins mainly trend NW-SE, NNE-SSW and E-W, N-S as to compare closely to the general trend of structures resulting from Pan-African orogeny. The mineralisation notably includes columbite-tantalite, rutile, cassiterites, ilmenites, wolframites, gold and gem stones. Geochemically, the trace elements concentrations shows significant anomalous concentrations of $\mathrm{Sn}, \mathrm{S}, \mathrm{Ti}, \mathrm{W}, \mathrm{Au}, \mathrm{Cu}, \mathrm{Ti}$ and $\mathrm{Nb}$ in the soil and stream sediments and $\mathrm{Sn}, \mathrm{W}$, and $\mathrm{Nb}$ in the veins. In addition, $\mathrm{Zn}, \mathrm{Cr}, \mathrm{Co}$, $\mathrm{Ni}, \mathrm{Cd}, \mathrm{Sb}, \mathrm{Mo}, \mathrm{V}, \mathrm{As}, \mathrm{Pb}, \mathrm{Rb}$ occurs in less significant anomalous concentrations in all the geologic media. The anomalous magnitude however decreases from soil to stream sediments and least in the veins. Further exploration work should be concentrated on soils and stream sediments towards delineating the possible ore deposit in the area of Kaiama and environs.

Keywords: Reconnaissance, Kaiama, Geochemistry, PIXE, XRF, Mineralization.

Copyright @ 2019: This is an open-access article distributed under the terms of the Creative Commons Attribution license which permits unrestricted use, distribution, and reproduction in any medium for non-commercial use (NonCommercial, or CC-BY-NC) provided the original author and source are credited.

\section{INTRODUCTION}

Minerals are the foundation of economic and industrial development of any nation. Machinery for manufacturing and other applications, production of chemicals for various industrial and domestic uses, energy generation, drugs for medical applications, research into new possibilities; in fact all aspects of human living is affected by minerals $[1,2]$. Thus it appears that the economies of nations driven by minerals are self-sustaining [3].

The basement complex of Nigeria has always been considered as a host for various mineralizations, with several works and publications done on several rocks and structures in the basement terrain, however, such works have not been previously done in the current part of the study area.

Jacobson and Webb [4] worked on the pegmatites of Wamba area (Central Nigeria) in a
400KM North-East South-West trending belt. Matheis $[5,6]$ studied the geochemical exploration for $\mathrm{Sn}-\mathrm{Nb}-\mathrm{Ta}$ in South-Western Nigeria. Matheis and Caen-Vachette [7] studied the pegmatites of Pan-Africa reactivation zone covering areas of Egbe, Ijero and Wamba, and also distinguished mainly between the barren and mineralized pegmatites.

Adekeye [8] followed up the earlier work of Jacobson and Webb [4] and reported traces of columbite and tantalite concentrates from pregmatite near Oke-Onigbin and Oro using heavy minerals from stream sediments survey. He concluded that there are no economic mineralization of columbite and tantalite in this area, he however found concentrates rich in magnetite, ilmenite topaz, garnet and tourmaline which are traced to mica schist, basic and pegmatitic rocks source in the area. 
Egbe-Isanlu schist belt is mineralized in iron iron banded formation (BIF) [9]. Other mineralizations in this belt include beryl, micas and tantalite in pegmatities around Ejuku and Ogbom [10], gold occur in quartz vein in association with pyrite, pyrrhotite, marcasite, chalcopyrite, argentite, pentlandite, magnetite, hematite, ilmenite, zircon, rutile and tourmaline [11], Akande et al. [12] and Garba [13].

Olobaniyi [10] also reported that the mineralized pegmatites (around Ejuku and Ogbom) have well-formed crystals of quartz, K-feldspar, mica, beryl and tantalite. Durotoye and Ige [14] and Akin-Ojo [15] have studied the chemical and physical properties of the Odogbe district talc and established its industrial suitability as raw material for refractories.

Bafor [16, 17] study and recognized Sudburytype mineral association in the Egbe-Based are of southwestern Nigeria. The area is underlain by amphibolitic rocks by which suggestion of a Red Seatype rift basin environment for the evolution of the rock types in Egbe-Isanlu area was made.

According to Obaje 2009, 90\% of Nigeria's total gold production has been from alluvial deposits derived from primary gold mineralization in the basement rocks. All the producing areas have been in the western part of the basement where the schist belts are best developed and there is a spatial relationship with some schist belts although gold quartz veins also occur in gneisses (e.g. Malele, Diko and Iperindo). Four gold fields have been outlined, Ilesha-Egbe, MinnaBirnin Gwari, Sokoto and Yelwa areas with each covering several thousand square kilometres[18].

Adekeye and Adedoyin [19] studied the Eruku pegmatites hosted in gneiss and grouped them into barren and mineralized pegmatites. The barren ones are simple in mineralogy and character and can serve as sources of ceramic and industrial minerals while the mineralized pegmatites are rich in columbite-tantalite, beryl, tourmaline, cassiterite and garnet.

The present work is aimed at employing geochemical composition of rocks, soil and stream sediments to define the ore forming elements distribution (dispersion and recognising type and area of possible mineralization in Kaiama and environ. A need for large scale mapping of parts of Kaiama Sheet 158 to understand its petrogenesis cannot be overemphasized. Also, the major rocks underlying basement rocks may or may not be mineral bearing. Mineralized rocks would also on weathering have mineralization signature in the soils generated and the stream sediment derived from such weathered rock and their sources.

There are no known publications on mineralization in Kaiama area of Kwara State. Hence is hoped to assist in addressing inadequacies in the geology and mineralization of Kaiama. These will also serve as a guide to investor and researchers that may want to further carry out research work in Kaiama.

\section{Location and Geologic setting}

Kaiama is the provincial capital of Kaiama Local Government Area in the northwestern part of Kwara State which itself is in the North-Central part of Nigeria. (Fig 1.2). It lies within the Federal Survey map of Nigeria Sheet 158, Kaiama SE. The area is defined by Latitude $\mathrm{N}^{\circ} 9^{\circ} 300^{\prime} 00^{\prime \prime}$ to $\mathrm{N}^{\circ} 9^{\circ} 45^{\prime} 00^{\prime \prime}$ and Longitude $\mathrm{E} 003^{\circ} 45^{\circ} 00^{\prime \prime}$ to ${\mathrm{E} 004^{\circ}}^{\circ} 00^{\circ} 00^{\prime \prime}$ covering an approximate area extent of about $770 \mathrm{~km}^{2}$ (fig. 1). Kaiama is a border town, approximately $60 \mathrm{~km}$ from the international boundary between Nigeria and Benin Republic. Major towns within the area includes Kaiama, Kugeji, Kimenji, Bezira, Karo, Shirigberia, Banisula. Zekana, Gbetekuta, Kurogun. Kaiama is bounded by Niger state to the north, Oyo state to the south, and Baruten LGA of Kwara State to the west (Fig 1). The people speak Bokobaru mostly but have pockets of Fulani and Nupe indigenes.

Kaiama is readily accessible through the Ilorin-Kishi, the Jebba - Kainji road and KosubosuYashikira road (Fig 1). The roads are yet to be fully constructed. There are many untarred rural roads linking the major settlements. In addition, numerous footpaths links the settlement and farmlands. These footpaths aid accessibility to the outcrops in the study area. The roads in the area are better traversed during the dry season as flooding can make the town inaccessible during the raining season.

Kaiama falls within the south-western Basement Complex of Nigeria. The major lithological groups within the Basement Complex of Nigeria can be grouped into four different rock suits, namely; the Migmatite Gneiss Complex (MGC), the Schist Belt (Meta-sedimentary and Meta-volcanic rocks), the Older Granites (Pan African granitoids), and the un-deformed Acid and Basic Dykes [20] (Fig. 2). These rocks constitute the Pre-Cambrian to Lower Palaeozoic Basement Complex rocks. The gneiss-migmatites bears imprints of the Liberian (ca. 2500Ma), Eburnean (ca. 2000Ma). 


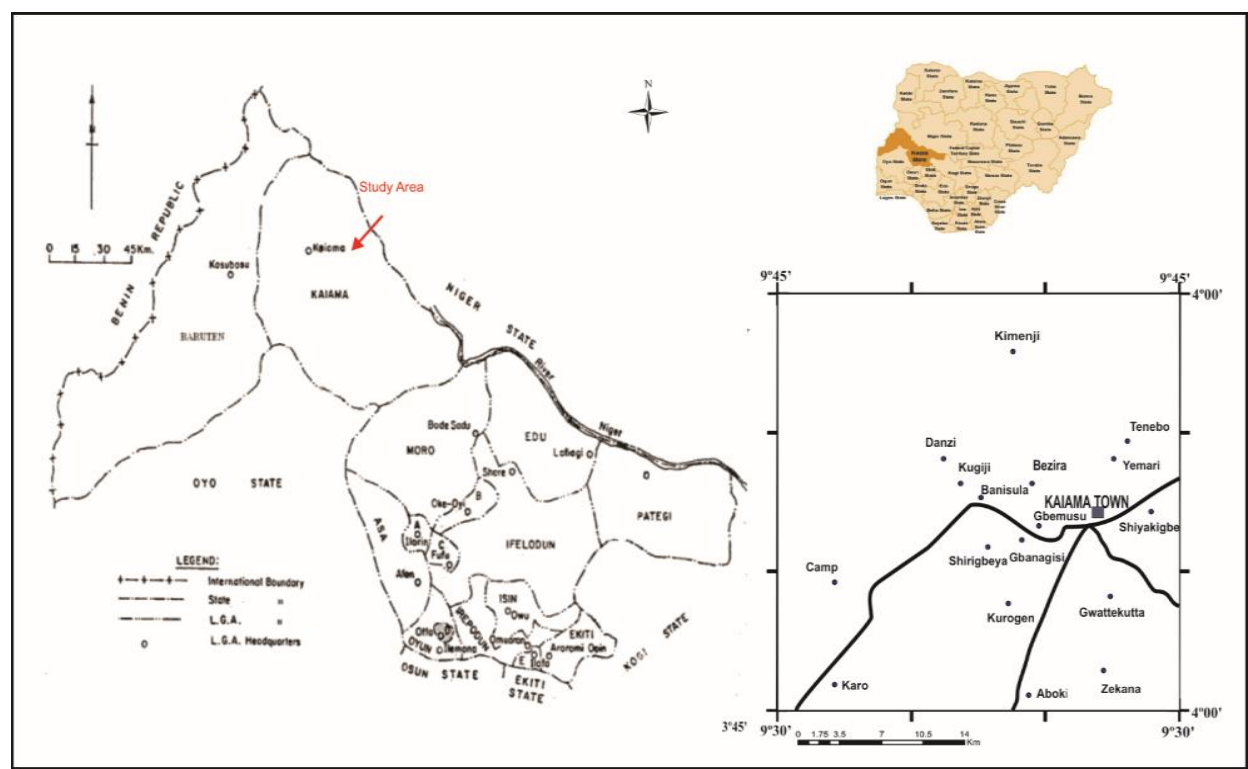

Fig-1: Location map of Kaiama and environs

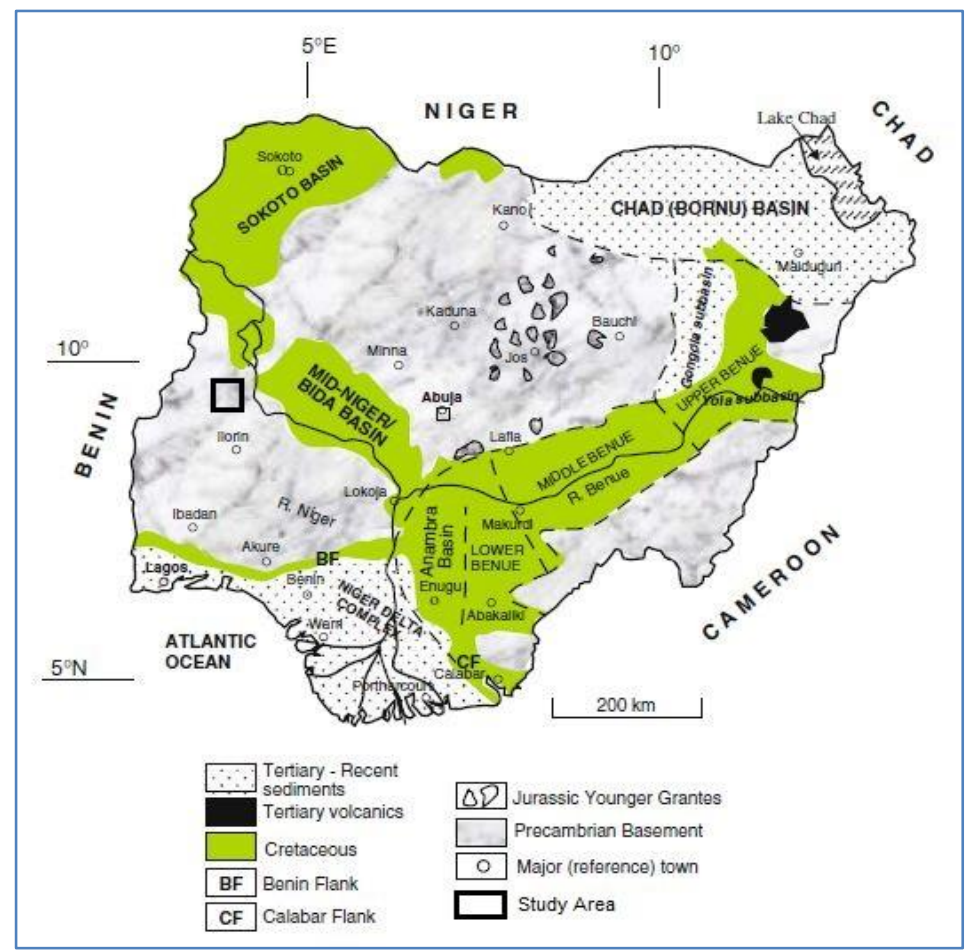

Fig-2: An overview of the geology of Nigeria showing the study area [20]

Pan African (ca. 600Ma) tectonic events [21, 22]. Within the sequence are domains of metasediments and meta-volcanics intruded by igneous rocks, which constitute the north/south trending schist belts. The schist belt lithologies which consist of fine grained clastics, pelitic schists, phyllites, banded ironformations, marble and amphibolites are considered to be Upper Proterozoic assemblages [22]. They host most of the economic minerals in the Basement Complex. During the Pan-African episode, the Proterozoic migmatite-gneiss schist complex were intruded by various granitoids resulting from oceanic closure, subduction, oblique collision between the West African
Craton and the Hoggar - Nigeria shields and crustal thickening [23].

The Nigerian basement complex is a polycyclic assemblage of heterogeneous migmatites and gneisses, metasediments and granites that have undergone a complex evolutionary history spanning through archaean to Pan-African (Late Proterozoic) times $[24,25]$. The rocks are believed to be the results of at least four major orogenic cycles of deformation, metamorphism and remobilization corresponding to the liberian $(2,650 \pm 150 \mathrm{Ma})$, the eburnean $(2,000 \pm 50$ $\mathrm{Ma})$, the kibaran $(1,100 \pm 200 \mathrm{Ma})$, and the Pan-African cycles $(600 \pm 150 \mathrm{Ma})$. Olade and Elueze [26], Ogezi 
[24] have favored largely ensialic processes in the evolution of the schist belts whilst Egbuniwe [27] stressed the importance of ensimatic processes in the formation of the schist belts.

The basement terrain is highly deformed as a result of various tectonic events with differing intensities. The resultant structure includes foliation (alternation of silicic-mafic minerals), minor folds, joints, fractures and faults. Each of the thermotectonic events produced characteristic imprints on the basement rocks. However, the Pan-African event was so pervasive that it nearly obliterated most of the structures of the earlier events, leaving behind mostly their traces [28-30]. Two major regional (transcurrent) fault systems (Anka-Yauri-Iseyin-AYI and KalangaiZungeru-Ifewara-KZI fault systems) trending NE-SW occur in Nigeria and these had probably developed during the late Pan-African orogeny [31]. These fault systems are dextral wrench faults with displacements in the order of tens of kilometers and have associated locally developed conjugate sinistral faults [32]. The most prominent structural trends are the N-S planar structures but relicts of E-W, NW-SE and NE-SW structures are preserved $[33,34]$.

The basement is also characterized by several sets of fractures with the north easterly and north westerly conjugate sets predominating [33]. ZungeruBirnin Gwari schist belt is a simple N-S syncline, 150 $\mathrm{km}$ long, with the northern part displaced dextrally by a NE-SW transcurrent fault. The Birnin Gwari schist belt occupies the synclinal axis of the belt and is characterized by conspicuous NNE-SSW trending ridges [35]. Kazaure schist belt is structurally simple, free from central granite intrusion and mafic igneous rock.

The Pan-African granites are usually elongated in a northern direction, an observation that shows that the Pan-African granite plutonism most probably exploited existing structures in the older basement [33]. Maru belt is a straight NNE-trending belt with a steeply dipping foliation [24]. Zuru schist belt can be described in terms of three phases of regional deformation D1, D2 and D3. D2, being the main cleavage-producing deformation phase that intensely folded the rocks into isoclinals N-S trending upright folds [36].

Locally, the various rock types within the study area include Granite, Schist, Migmatite, Quartz vein, Amphibolite, and Pegmatite vein. The pegmatite vein and the quartz vein are the main host of economic mineral signatures within the area of study of Kaiama.

\section{METHOD}

Reconnaissance geochemical survey of the area of Kaiama was undertaken towards detecting and revealing the type of ore mineralization in the area. The methods adopted are broadly grouped into three (Fig.
3), namely; Desktop and pre-field studies; Ground geological mapping and Sampling; and Laboratory geochemical composition analysis.

The Desk study involved literature review where various works that have been published on the mineralization potential of the basement rocks of Nigeria were reviewed. Most of these works made use of methods such as geochemical analysis and geological mapping. Satellite imageries of the Kaiama area were acquired and studied. The satellite images were acquired from Landsat 8 Operational Land Imager (OLI). Also, an Advanced Space borne-Thermal Emission and Reflection (ASTER) Global Digital Elevation Model (GDEM) draped on topographic map of the study area was used for the interpretation of physiographic features to aid reconnaissance field work. Subsequently, subsets of the Landsat 8 scene (Path 191/Row 053, acquired on November 27, 2017) were processed using the ENVI 5.1 image processing and analysis software. Principal Component analysis image PCA Image was used to reveal mineral alteration types in the study area. Map of Kaiama was scanned and uploaded into MapInfo software (MapInfo Professional 11.0) and digitized on a scale of 1:50,000 map.

A field exercise was carried out to documents the types, occurrence and distributions of the lithologies underlying the area of Kaiama. With the aid of the principal component analysis (PCA) map generated from the remote sensing studies, area of high alterations are noted The area was traversed on foot and motorcycles for a period of one month during April and November 2017. The use of directional and orientation tools including global positioning system (GPS) and compass clinometer compass.

Representative samples of rocks were collected with the aid of block head hammer and chisel for petrographic studies. Using shovel and digger twentyOne pit at $2 \mathrm{~m}$ deep (Fig. 4) were dug at random but representative locations for soil samples and stream sediments along topographic lows and dried flood plains, cares was taken to exclude plant litters, roots and rock fragments $[37,38]$ randomly while some in the mining pit with the aid of digger and shovel to collect soil sediment and placed in a plastic self-seal bags for geochemical analyses. Locations of samples were taken and recorded while collected samples were carefully labeled and stored in polythene and cotton bags for further laboratory studies. Pictures of exposures were also taken using digital cameras.

Three field sampling pans were used to sample $20 \mathrm{~kg}$ stream sediments collected from first/second order streams (inner bent) from predetermined stream locations and hand dug pits were panned to recover heavy fractions that ore minerals are concentrated. The panning was carried out both on the field (streams) (Fig. 5, Fig. 6) and Sedimentology Laboratory of Department 
of Geology, University Of Ilorin, Ilorin. The locations of the various samples collected are shown in Figure 8.

The methodological process employed in the laboratory for the purpose of this study are; geochemical analysis for major, minor and trace elements and a petrographic study involving preparation and description of thin sections under petrological microscope.

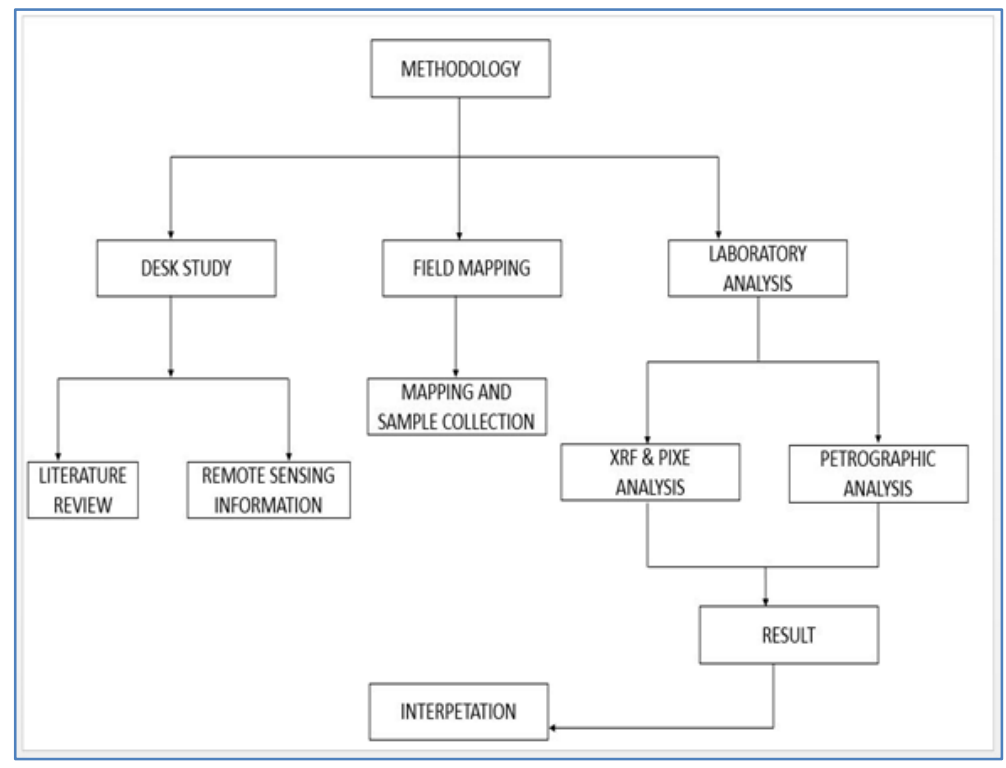

Fig-3: Flow chart showing method used

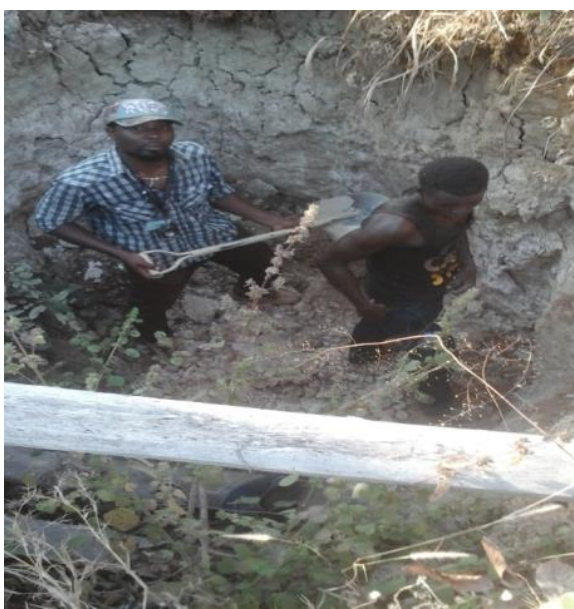

Fig-4: Pitting in Karo, Kaiama

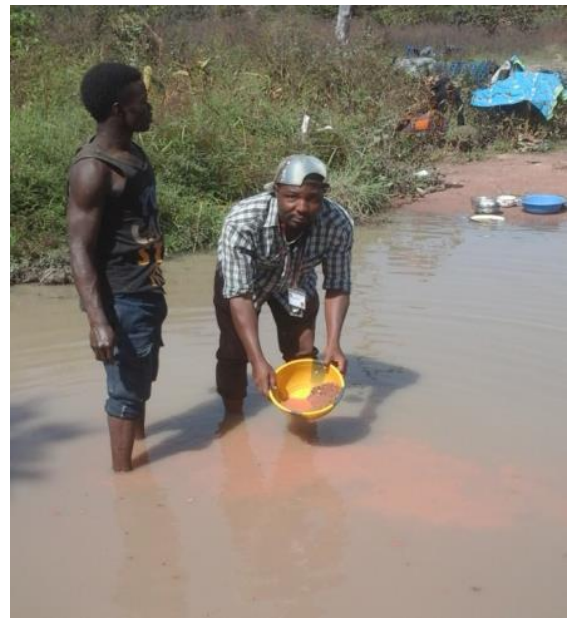

Fig-5: Panning at mining site, Shirigbeya

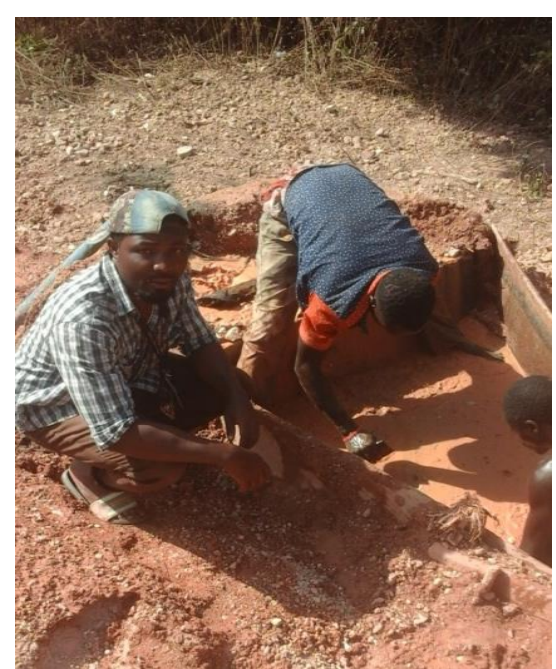

Fig-6: Ore gangue separation at Shirigberia

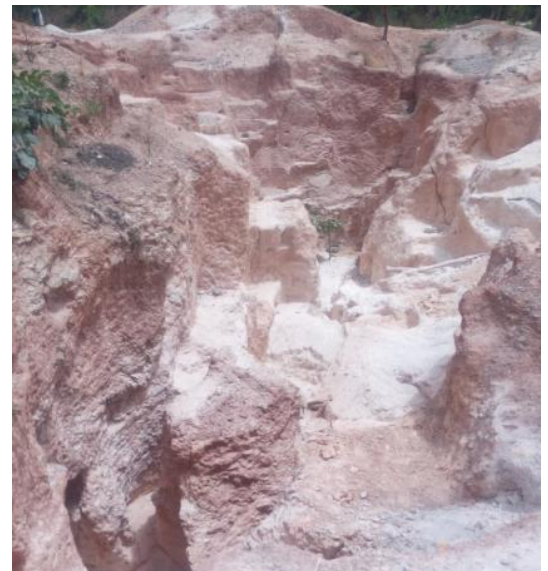

Fig-7: Open mine at Shirigberia (Daba) mine site 


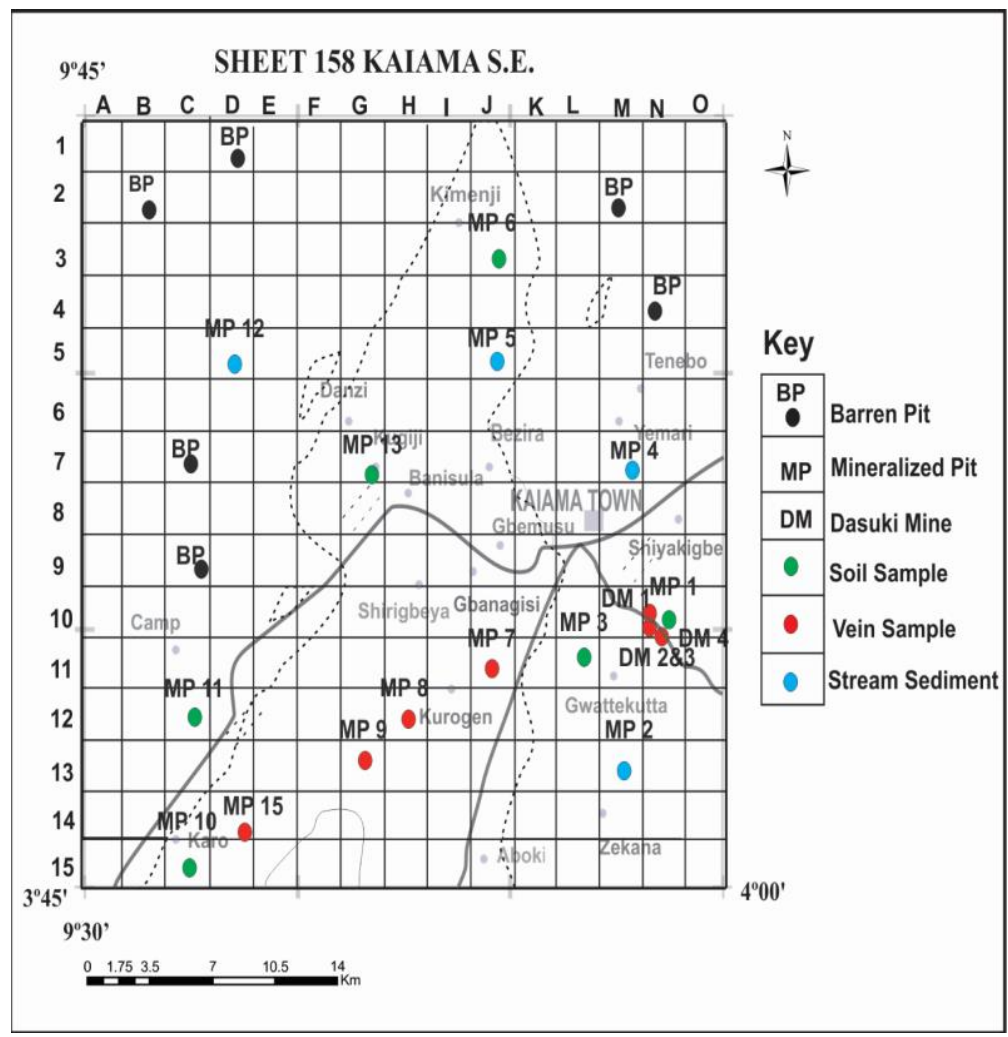

Fig-8: Location of sample collected for geochemical and petrological studies from Kaiama and environs

Rocks underlying Kaiama and environ have also been studied and described petrologically for the present studies. The texture, micro-structure and mineralogical compositions of solid geological material are commonly studied and described using petrological microscope.

Thin sections of rocks were prepared using facilities available at the geological workshop of the department of Geology and Mineral Sciences, University of Ilorin. A total number of six representative selected rocks, their samples were studied under a polarizing petrological microscope and photomicrographs taken with digital camera. JMicroVision software was used for modal mineralogical composition from point counting.

Selected rock were cut, crushed, quartered and pulverized for representative sample to be analyzed for geochemical composition, heavy fractions of soils and stream sediments obtained from panning were aired dried at room temperature after which they were also crushed, quartered and pulverized for major and trace geochemical composition analysis.

The geochemical composition analysis was performed using are the $\mathrm{X}$-ray Fluorescence Spectrometer (XRF) and Particle Induced X-ray
Emission Spectrometer (PIXE). The XRF was basically used to analyze for the major elements constituent while PIXE was used for trace elements contents.

Analysis by XRF and PIXE was carried out at the laboratory of Energy Research Centre O.A.U Ile-Ife while complementary XRF was undertaken at the laboratory of Dangote Cement Ltd, Obajana kogi state.

\section{RESULTS \\ Remote Sensing}

Fig. 9 shows pixels of anomalous concentration in hydroxyl and iron oxides bearing minerals as brightest pixels was created by merging of hydroxyl bearing image and iron oxide bearing image, by using Crosta technique [39]. This new image was combined with the other two in a RGB composite (Iron oxide bearing image, iron oxide and hydroxyl bearing image, hydroxyl bearing image). A colour image resulted where bright pixels within alteration zones are areas where both iron stained and argilized; bright reddish to dark orange correspond to areas more argillaceous than iron stained; bright cyan to bluish zones are more iron stained than argilized. Bright colours represent hydrothermal alteration zones, blue to cyan colours represent zones of iron oxides while brown to yellow represent areas of clay alterations. 


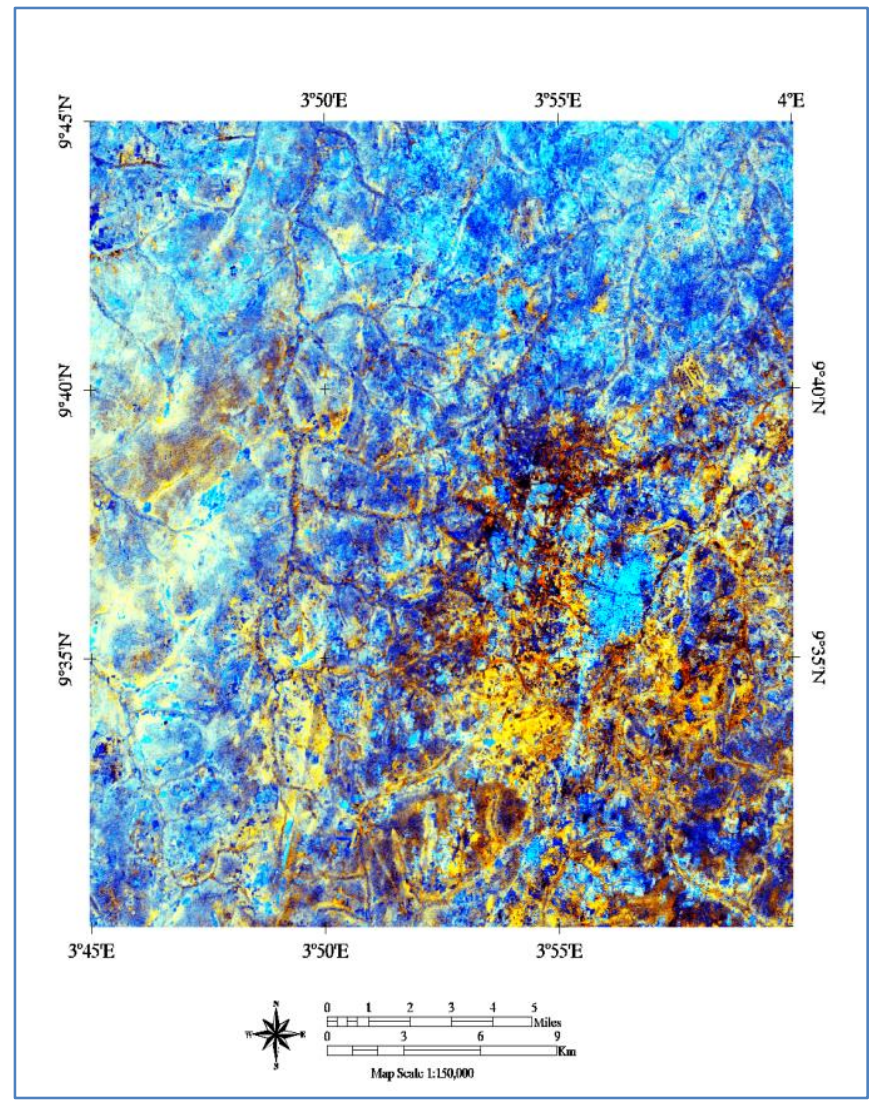

Fig-9: PCA Component Analysis image of the study

\section{Geology and Structural mapping}

The studied area Kaiama is situated in the Precambrian basement complex of south western Nigeria. The rocks underlying the area are dominantly occurring as low lying ridges except for few exceptions that are elongated. A map showing the distribution of rocks in Kaiama is shown in Figure 10. . Kaiama is made up of various rock types which can be classified into two groups; Major rocks: granites, migmatites, schists, and amphibolites, and the Minor rocks: pegmatite and quartz veins.

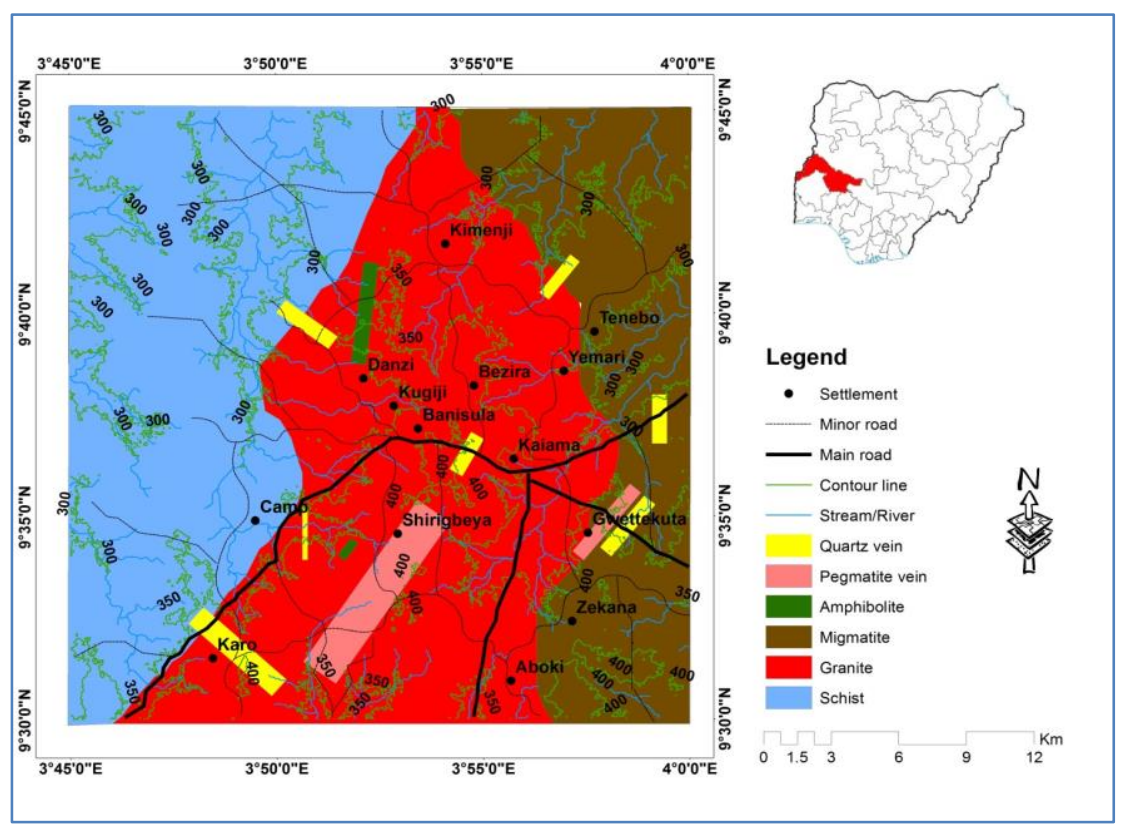

Fig-10: Geological map of Kaiama and environs 


\section{Granites}

Granites are the most dominant outcrop in the study area. They cover about $60 \%$ of the study area. They mostly occur in the central part of the study area and trends in a NNE-SSW direction. The granites are diverse in texture; porphyritic, phaneritic and aphanitic texture are all present in Kaiama. They are variably coloured grey, white and pink.

The fine grained Granites are seen mostly occur around Kugeji and Bezira as minor bodies within the porphyritic granites. They are exposed as low lying scattered fractured and jointed boulders ranges in size from $0.5-1 \mathrm{~m}$ sized, their mineralogy comprised quartz, feldspar and mica. The fine grained granites towards camp are not only low lying but generally weathered.

\section{Porphyritic Granite}

Porphyritic Granites are the most dominant in Kaiama and environ, they form hills and ridges and widely distributed especially around Kaiama township, Aboki, Kurogen, Shirigberia, Kimenji, Banisula, Kugeji, and Bezira. They mostly occur as a low lying exposure except in Kaiama town where they formed a huge hill of up to $50 \mathrm{~m}$ above the ground. Mineralogically, the porphyritic granites are similar in composition to the fine grained granites but with the larger feldspar phynocryst $(0.5-6 \mathrm{~cm})$ size and euhedral crystals which are randomly oriented, although in places they show tendencies of NE-SW or E-W orientations. The sizes of quartz and feldspar phenocrysts ranged from $2 \mathrm{~mm}-2 \mathrm{~cm}$.

\section{Petrography}

The feldspar phenocryst appears as large leucocratic crystal, highly sheared and cracked, with slight alteration along the cracks with inclusions of opaque minerals. Micro structures of joint could be seen on the crystals, and with perfect cleavages. The biotites appeared mottled in appearance which characterizes micas and mostly close to extinction. (Figs.10 a and b). Mineral compositions of the porphyritic granites are shown in Table 1.

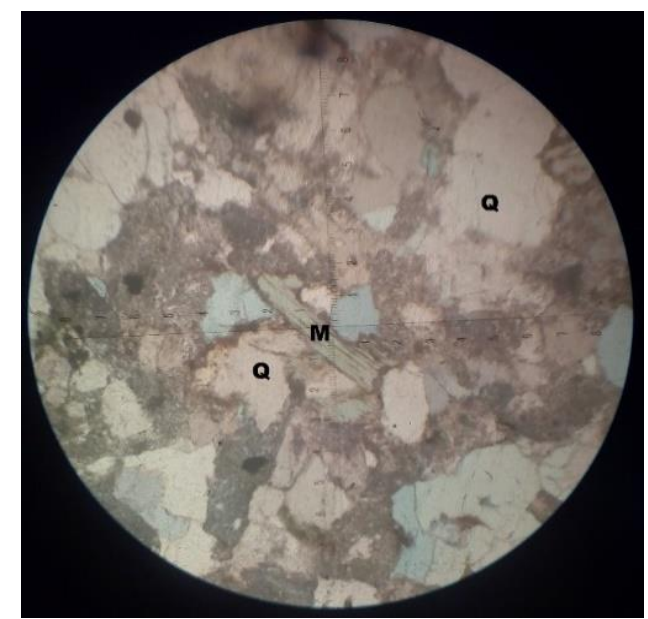

Fig-10a: Bezira 4kR1 fine grained granite PPL Mag x40

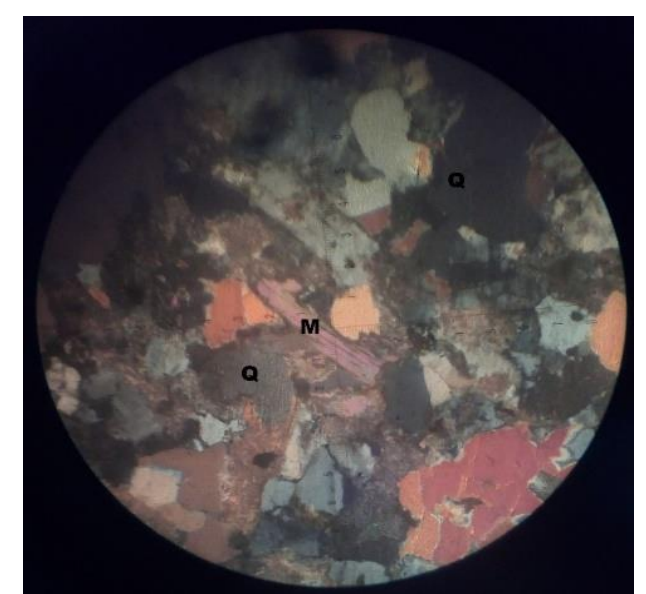

Fig-10b: Bezira 4KR1 XPL Q= Quartz, M= Muscovite

\section{Phaneritic Granite}

Phaneritic Granites are outcropped at Kugiji as low ridges. They are coarse textured granites with subhedral quartz crystal in hand specimen. Their colour ranged from white to grey. Thin section revealed plagioclase feldspar which are highly sheared with irregular basal cleavages, microcline with lamellae twinning under plain polarised light, and quartz crystals which appear greyish under cross polar with undulose extinction and a weak birefringence. Modal composition of the pheneritic granites are given in Table 1.

\section{Migmatites}

Migmatites occurs as poorly exposed low lying bodies around Zekena, Yemari, Tenebo, Gwettekuta, and Shiyakigbe. The paleosome within the migmatite appeared to be felsic in appearance and composition while the neosome is quartzofelspathic. The paleosome and the neosome occur in an alternating parallel manner forming a stromatic pattern. Migmatite has a mineralogical composition of quartz, orthoclase, feldspar, hornblende and micas (muscovite or biotite). Strike-slip faults and series of folds can be observed on the migmatite. Commonly, they occur within extremely deformed rocks (polycyclic deformation) that represent the base of eroded mountain chains, typical of Precambrian cratonic blocks [25].

\section{Schist}

Schist occurrences are as highly weathered and poorly exposed bodies in the studied area of Kaiama and environs. They are mostly restricted to the western part of the studied area with $\mathrm{N}-\mathrm{S}$ trending foliations. Notable Schist exposure was seen along the road from Karo to Camp and around Kugeji - Nanu road. Schists are a group of medium grade metamorphic rocks, which are characterised by medium to coarse grained minerals that are platy or flaky in appearance and are highly weathered. Where relatively fresh the schists are dominantly composed by biotite and quartz. 


\section{Amphibolite}

This is a metamorphic rock composed mainly of amphibole which gives it a very dark to dark green coloration. Amphibolites account for about $5 \%$ of the total rock units within the studied area of Kaiama. It is confined to the western part of the studied area and in proximity to the schists. Amphibolites also occur along Kugiji - Nanu road and Shirigbeya. Texturally, it appears as medium to fine-grained in hand specimen and mineralogically shows Quartz, Biotite, and amphibole.

\section{Petrography}

The Amphibolites is mainly composed of plagioclase, biotite and quartz as shown in Table 5.2. Plagioclase is the dominant mineral within (49\%) it and it occurs as equigranular grains that have undulose extinction, low relief, pleochroic and twinned. Associated minerals are quartz $(20 \%)$, and biotites $(15 \%)$. The biotites are subhedral and platy crystals often aligned or oriented. Quartz which occurs in minor amount occurs as anhedral equigranular grains with undulose extinction and a low relief (Fig. 11 and b).

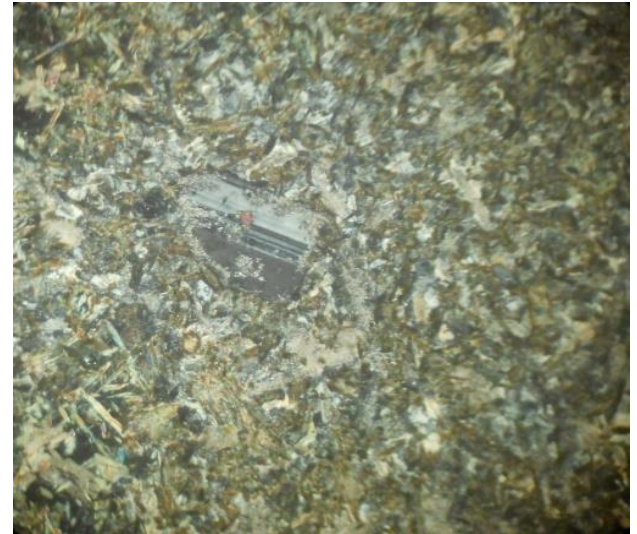

Fig-11a: Nanu KMB8 Amphibolite PPLx40

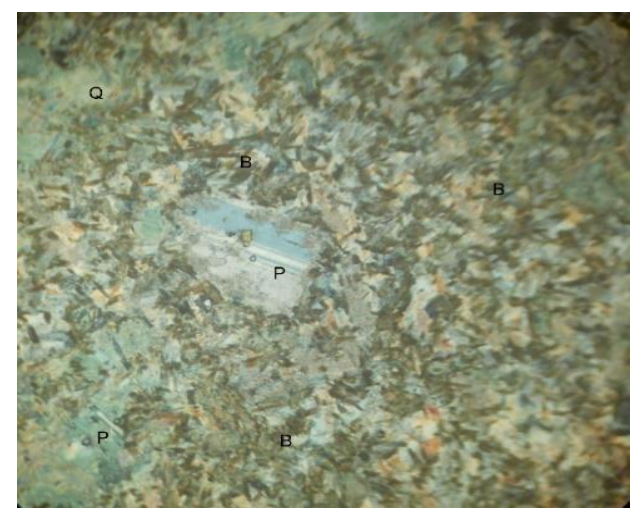

Fig-11b: Nanu Amphibolite XPL

$P=$ Plagioclase, $\mathbf{B}=$ Biotite, $\mathbf{Q}=$ Quartz

Table-1: Average Modal Analysis

\begin{tabular}{|l|l|l|l|l|l|l|l|l|}
\hline SAMPLE NO & QTZ & MCL & PLG & BIO & HNB & MSC & ACS & OPQ \\
\hline 2KRR2 & 80 & - & - & - & - & - & 12 & 8 \\
\hline 2KRS1 & 80 & - & - & - & - & - & 15 & 5 \\
\hline 4KRS1 & 35 & 19 & 21 & 15 & - & 5 & 3 & 2 \\
\hline 4KRS2 & 32 & 16 & 24 & 15 & - & 5 & 7 & 1 \\
\hline 4KRS3 & 31.5 & 14 & 18.5 & 12 & & 11 & 10 & 2.5 \\
\hline KMB 8 & 22.1 & - & 48.6 & 15.1 & 10.2 & 3.4 & - & 0.6 \\
\hline
\end{tabular}

\section{Pegmatite Vein}

Pegmatite occurs as variably sized $(2 \mathrm{~cm}$ to $100 \mathrm{~m}$ ) vein bodies in Kaiama. The pegmatites cut across all major lithologies including granite, migmatite and schist. They consist of both simple and complex pegmatites trending N-S and E-W. The pegmatites are composed of large crystals of quartz, feldspar, biotite and muscovite micas. In places, the pegmatites occurs weathered (Fig 12).

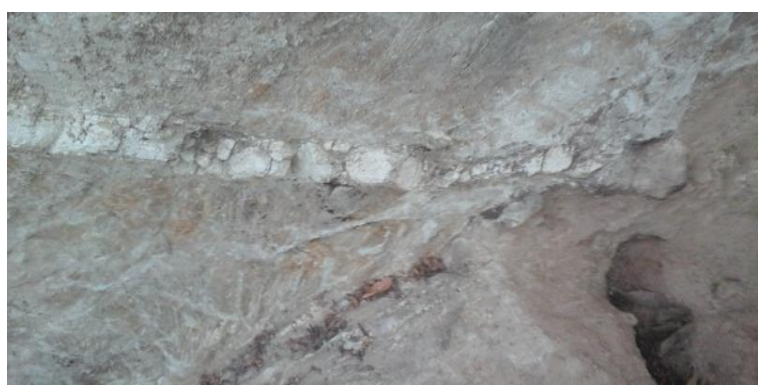

Fig-12: Pegmatite vein on weathered schist, Karo
Pegmatites occurring around Karo are pinkcoloured and hosting gems-quality 1-3 cm sized transparent and smokey quartz. Kaolinitized pegmatite veins at Kanikoko road and Shirigberia have associated cassiterite and tantalite ore minerals (Fig 13, 14 and 15).

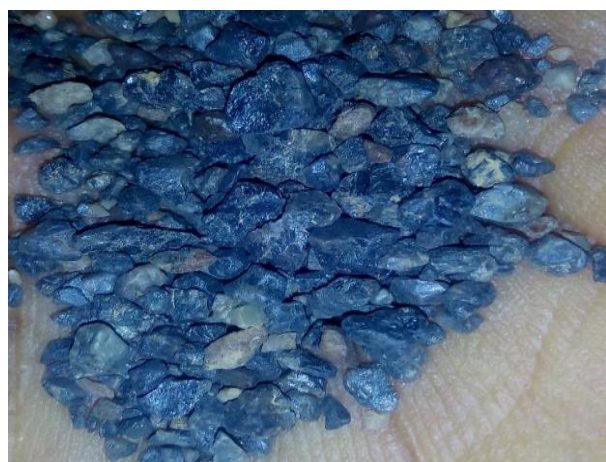

Fig-13: Tin Ore from the study area(Kaiama) 


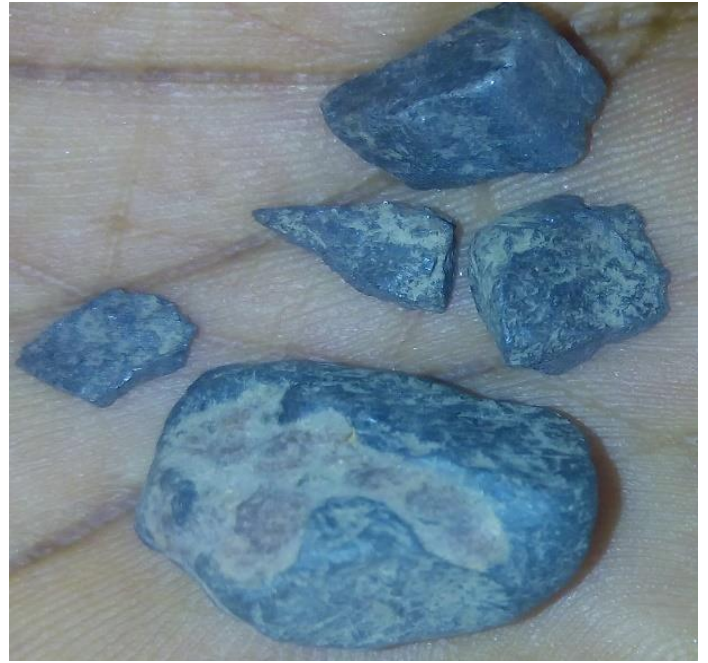

Fig-14: Tanatalite Ore from Shirigbeya Mine

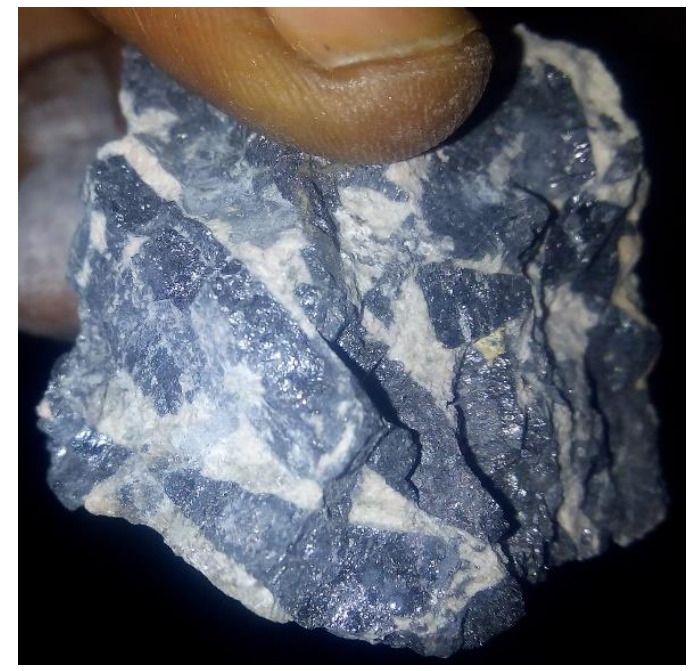

Fig-15: Kaolinized Wolframite Ore, Shigbya

\section{Quartz vein}

Quartz vein occur infrequently within granites and migmatites. A very prominent quartz vein occurs as 2-3 km long ridge at the southeast of Karo (Fig. 5.7). Small quartz vein bodies occur in Kanikoko, Zekanna, Kemenji and Camp area whilst boulders of quartz vein were found near Kugeji as a low lying discontinuous outcrop. In places, the quartz vein exposures are variably coated by yellowish to reddish coloured iron oxides. The quartz veins are mostly fractured and sheared as to be regarded to be 'cataclasts'. Quartz vein occurrences around Kugeji cut across fined grained pink granite with the veins varying in thickness from 3 $\mathrm{cm}$ to $30 \mathrm{~cm}$ and having minor muscovite content. The quartz vein generally grossly trends E-W and NE-SW and, at Kanikoko, Shirigberia, and Kirinkirin host cassiterite, wolframite and tantalite ores.

\section{Petrography}

Where sheared, quartz crystals occurred as flattened and elongated fractured interlocking domains. Quartz characterized by whitish to green birefringent colors under cross polar with parallel extinctions which although is not uniform due to deformation and partial recrystallizations (Fig. 16a and b).

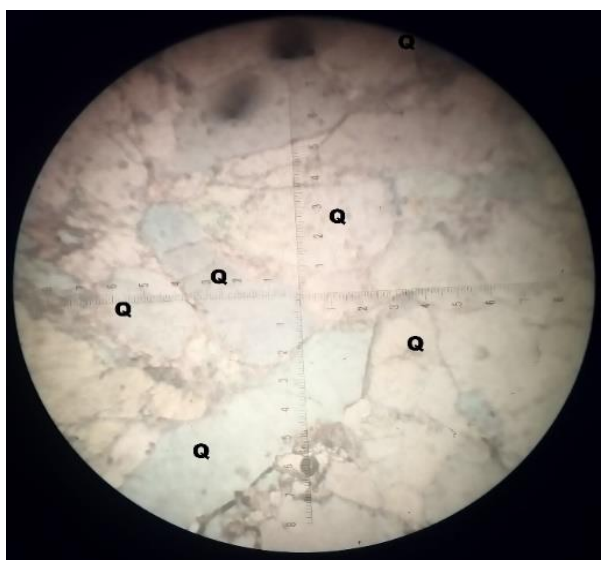

Fig-16a: Karo Quartz vein 4KR1b PPL x40

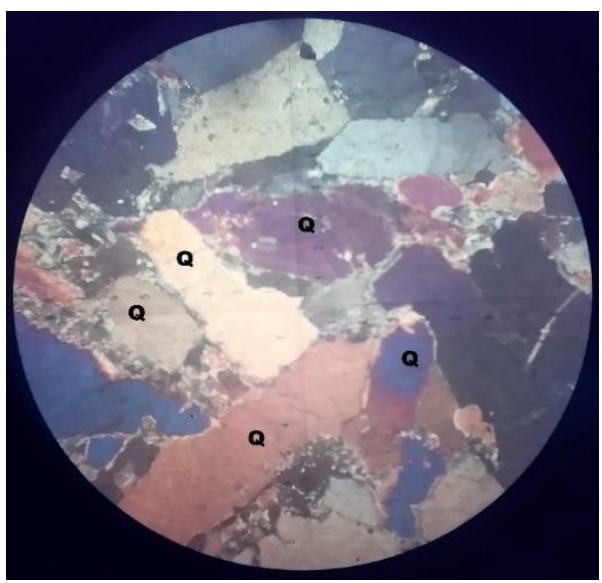

Fig. 16b: Karo Quartz vein 4KR1b in XPLx40 Q= Quartz

The types of brittle structures found in the study area are faults, joints, dike, vein, and xenolith.

i) Fault: Faults were observed on all the rock units underlying Kaiama. This informs that Kaiama area has been affected by deformations within in a measurable displacement. This area has suffered both dextral and sinistral displacements as evidence of multiple movements. Notable is the faults were on the migmatite around Zekana and in the quartzofelspathic veins within the granites around Kaiama township.

ii) Joint: Joints are discontinuity surface with no measurable shear displacement. It was observed in almost all the rocks in the study area. All veins are joint-controlled and they occur as fracture infillings in the major rock units. The joints trends are plotted in Fig. 17. The joints dominantly trend in NE-SW and N-S directions while few others trend in the E-W direction.

iii) Veins: Veins are fractures within which rocks and minerals have precipitated from late magmatic fluids. The pegmatites and quartz veins occur commonly composed of feldspar, quartz, mica and with or without ore minerals. The trends are plotted in (Fig. 18). They 
trend dominantly NW/SE with complementary E-W and NW/SE trends

Ductile Deformation refers to the capacity of a rock to deform to large strains without macroscopic fracturing. This behavior may occur in unlithified or poorly lithified sediments, in weak materials such as halite or at greater depths in all rock types where higher temperatures promote crystal plasticity and higher confining pressures suppress brittle fracture [30]. This deformation leads to the formation of certain structures and some of the structures described above. Ductile deformations within the studied area of Kaiama include; folds, foliations and shearing.

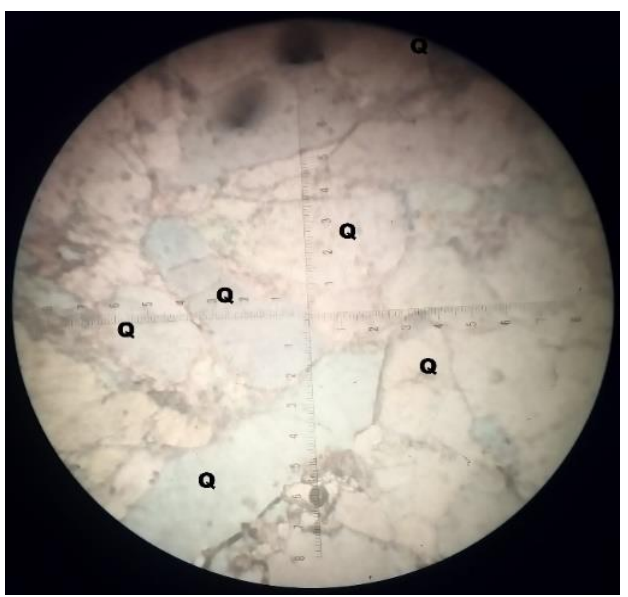

Fig-5.24: Karo Quartz vein 4KR1b PPL x40

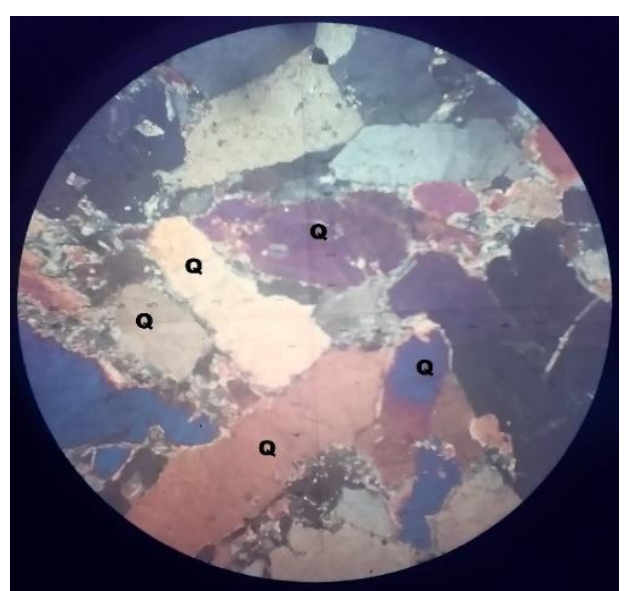

Fig-5.25: Karo Quartz vein 4KR1b in XPLx40 Q= Quartz

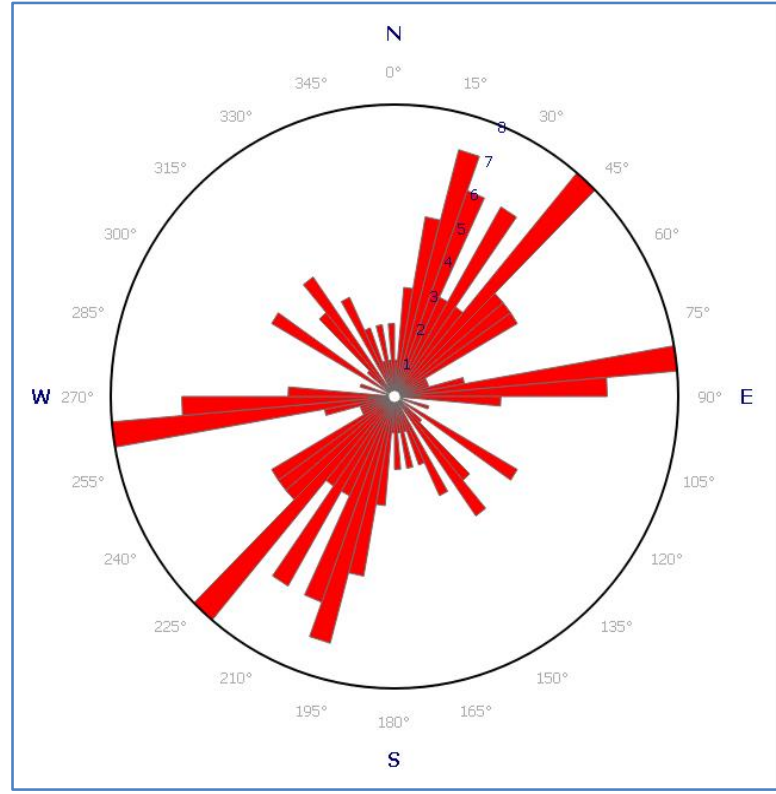

Fig-17: Orientation of Joints in the study area

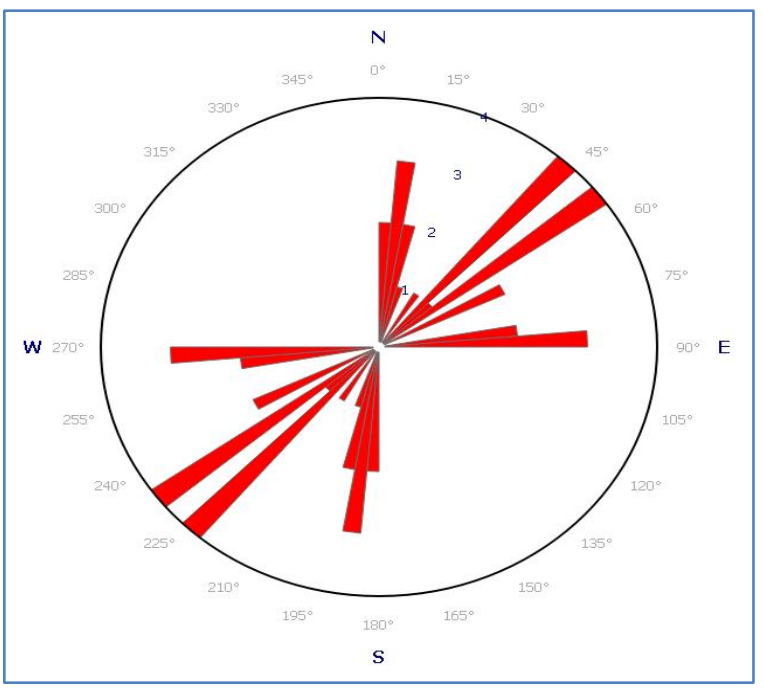

Fig-18: Orientation of veins in the study area

\section{Geochemical Composition}

The trace element geochemical compositions of veins, soil, and stream sediments in Kaiama are given in Tables 5.4, 5.5, and 5.6. The analytical result has provided insight into the concentration level of occurrence and distribution of the elements within the geologic media of Kaiama.

\section{Major Oxide Geochemistry}

Tables 2, 3, and 4 below shows the major element concentrations within quartz/pegmatite veins, soil samples, and stream sediment samples within Kaiama and environs. 
Table-2: Major Oxide concentration in Veins samples within the Kaiama

\begin{tabular}{|l|l|l|l|l|l|l|}
\hline Location & & & & & & \\
\hline Element & DM1 & DM2 & DM3 & DM4 & MP14 & MP15 \\
\hline $\mathrm{SiO}_{2}$ & 57.54 & 55.29 & 34.61 & 47.40 & 21.11 & 45.36 \\
\hline $\mathrm{Al}_{2} \mathrm{O}_{3}$ & 0.32 & 0.36 & 7.54 & 3.34 & 3.92 & 9.42 \\
\hline $\mathrm{FeO}$ & 1.69 & 1.51 & 2.53 & 2.19 & 1.35 & 2.92 \\
\hline $\mathrm{CaO}$ & - & - & 0.10 & 0.18 & 0.24 & - \\
\hline $\mathrm{Na}_{2} \mathrm{O}$ & - & - & 6.37 & 0.08 & 0.13 & 0.09 \\
\hline $\mathrm{K}_{2} \mathrm{O}$ & 0.04 & 0.07 & 0.12 & 0.57 & 2.21 & 3.27 \\
\hline $\mathrm{MnO}$ & 0.01 & 0.02 & 0.04 & 0.59 & 7.23 & 0.15 \\
\hline $\mathrm{TiO}_{2}$ & 0.01 & 0.01 & 0.1 & 0.05 & 0.26 & 0.18 \\
\hline $\mathrm{P}_{2} \mathrm{O}_{5}$ & 0.14 & 0.1 & 0.09 & 0.15 & 0.43 & 0.08 \\
\hline
\end{tabular}

Table-3: Major Oxide concentration in Soil samples within the Study area

\begin{tabular}{|c|c|c|c|c|c|c|c|}
\hline Location & & & & & & & \\
\hline Element & MP1 & MP3 & MP6 & MP8 & MP9 & MP11 & MP13 \\
\hline $\mathrm{SiO}_{2}$ & 27.26 & 38.84 & 21.59 & 16.3 & 32.61 & 32.68 & 34.83 \\
\hline $\mathrm{Al}_{2} \mathrm{O}_{3}$ & 4.83 & 2.98 & 4.23 & 6.39 & 9.93 & 8.26 & 4.61 \\
\hline $\mathrm{FeO}_{3}$ & 10.1 & 2.29 & 31.28 & 3.23 & 7.69 & 62.84 & 33.94 \\
\hline $\mathrm{CaO}$ & 2.12 & 0.18 & 0.13 & 2.88 & 0.21 & 2.82 & 0.14 \\
\hline $\mathrm{MgO}$ & 3.23 & 0.07 & - & - & 7.81 & - & - \\
\hline $\mathrm{Na}_{2} \mathrm{O}$ & - & 0.56 & - & - & - & - & - \\
\hline $\mathrm{K}_{2} \mathrm{O}$ & 0.8 & 1.75 & 0.41 & 1.12 & 2.56 & 0.76 & 1.39 \\
\hline $\mathrm{MnO}$ & 2.05 & 0.07 & 1.14 & 1.86 & 5.17 & 0.29 & 1.44 \\
\hline $\mathrm{TiO}_{2}$ & 3.62 & 0.99 & 43.37 & 3.51 & 2.66 & 1.83 & 43.20 \\
\hline $\mathrm{P}_{2} \mathrm{O}_{5}$ & 0.58 & 0.11 & 13.21 & 0.55 & 0.48 & 0.32 & 0.82 \\
\hline
\end{tabular}

Table-4: Major Oxide concentration in Stream sediment samples within Kaiama

\begin{tabular}{|l|l|l|l|l|l|}
\hline Location & MP2 & MP4 & MP5 & MP7 & MP12 \\
\hline $\mathrm{SiO}_{2}$ & 24.32 & 29.25 & 41.66 & 22.88 & 45.95 \\
\hline $\mathrm{Al}_{2} \mathrm{O}_{3}$ & 4.55 & 3.67 & 3.98 & 2.19 & 14.59 \\
\hline $\mathrm{FeO}_{3}$ & 41.60 & 40.6 & 30.37 & 13.18 & 21.23 \\
\hline $\mathrm{CaO}$ & 0.37 & 0.31 & 0.14 & 0.08 & 32.94 \\
\hline $\mathrm{K}_{2} \mathrm{O}$ & 0.92 & 1.38 & 0.61 & 0.49 & 0.34 \\
\hline $\mathrm{MnO}$ & 1.34 & 0.85 & 1.16 & 0.69 & 0.21 \\
\hline $\mathrm{TiO}_{2}$ & 52.42 & 72.36 & 46.25 & 92.29 & 0.62 \\
\hline $\mathrm{P}_{2} \mathrm{O}_{5}$ & 0.90 & 0.8 & 0.62 & 1.63 & 0.45 \\
\hline
\end{tabular}

\section{Trace element Geochemistry}

The trace element geochemical composition of the rocks, soils, and stream sediments of Kaiama are given in Tables 5, 6, and 7. The element concentrations have also been considered relative to the abundances of the elements in the crust and granite (Table 8).

From Table 5.7 (pegmatite and quartz veins), compared to the upper crust and granites, the vein rocks of Kaiama are only significantly anomalous in the respect of $\mathrm{W}, \mathrm{Sn}, \mathrm{Ta}$, and to a very low extent, $\mathrm{Cu}$ and $\mathrm{Au}$. W only occur in very significant amount in the eastern part of Kaiama (sample DM4). It occurred in association with $\mathrm{Sn}$ whose presence was recorded in all the locations especially at Shirigberia (MP14) and eastern outskirt of Kaiama (DM4) with abundance of $17645 \mathrm{ppm}$ and $7082 \mathrm{ppm}$ respectively. Sn occurred in lesser amounts of 56-482 ppm at the other locations. Tantalum occurred only anomalously at Shirigberia 452
- 10,935 ppm concentrations. All other trace elements occur in concentration within the range recorded in crustal rocks and hence are not of mineralisation.

The soils from Kaiama and environs (Table 6) shows high anomalous abundance of $\mathrm{W}, \mathrm{Sn}, \mathrm{Nb}$, and Ti. $\mathrm{Sn}$ is the dominant trace element but anomaly occurring in amounts of 230 to $522 \mathrm{ppm}$ at most localities exception being the highest at Shirigberia (Samples MP 8 and MP9) and eastern outskirt of Kaiama Township (MP1). The $\mathrm{Nb}$ and $\mathrm{W}$ distribution were similar to $\mathrm{Sn}$ with W being highest (21716 ppm) to the east of Kaiama Township whereas $\mathrm{Nb}$ is mostly in the soils at Shirigberia to the south in amount of $1980-2574 \mathrm{ppm}$. Ti show widespread high abundance throughout the area of study. Its abundance varies from $594 \mathrm{ppm}$ to $25999 \mathrm{ppm}$. It would be occurring as $\mathrm{Ti}$ oxide or accompanying $\mathrm{Nb}$, Ta minerals. Many other trace elements notably including $\mathrm{Zn}, \mathrm{Cr}, \mathrm{Co}, \mathrm{Pb}, \mathrm{Ni}, \mathrm{Cu}$, and 
Cd occur in concentrations relatively higher than in the crustal rocks. They are mobile elements whose release and weathering environment will be preferentially concentrated in soils (ref). Very significantly, Au was recorded present in high amounts of $8452 \mathrm{ppm}$ in the eastern outskirt of Kaiama (sample MP1). Lesser amount of $\mathrm{Au}(84-300 \mathrm{ppm})$ also occurred in the soils at Shirigberia. There would appear that the Sa-Nb-Ta mineralization in Kaiama and environs has gold associated with it.

The stream sediments (Table 7) are characterized by anomalous high concentration of $\mathrm{Ti}$, $\mathrm{W}, \mathrm{Nb}$, and $\mathrm{Sn}$ with respect to crustal rocks and granites. The sediments are particularly rich in $\mathrm{Ti}$ significantly varying from $371 \mathrm{ppm}$ to $3.38 \%$ with the highest abundance occurring at Gberia to the south. W occurred in anomalous 114 to $2153 \mathrm{ppm}$ with the highest occurring in the eastern outskirt of Kaiama. Sn and $\mathrm{Nb}$ have similar distribution throughout the area with the abundance of Sn (45 to $1377 \mathrm{ppm}$ ) being twice to thrice that of $\mathrm{Nb}(33-790 \mathrm{ppm})$. Other trace elements of lesser anomalous significance are Co (81 852 ppm), V 940 - 320 ppm), Cu (19 - 439 ppm) and $\mathrm{Sb}(96-508 \mathrm{ppm})$. There elements would probably be incorporated into or associated with the crystal structures of the immobile iron oxide phases in the stream sediments (cf Table 4).

Table-5: Trace Element concentration in Vein samples within the Kaiama

\begin{tabular}{|l|l|l|l|l|l|l|}
\cline { 1 - 1 } Location & \multirow{2}{*}{ Dlement } & DM2 & DM3 & DM4 & MP14 & MP15 \\
\cline { 1 - 5 } $\mathrm{S}$ & 882 & 45 & 13 & 27 & & 5 \\
\hline $\mathrm{Ti}$ & 5 & 5 & 61 & 29 & 155 & 107 \\
\hline $\mathrm{V}$ & 1 & & 1 & - & - & - \\
\hline $\mathrm{Zn}$ & 10 & 5 & - & - & 52 & 6 \\
\hline $\mathrm{Cr}$ & 52 & 49 & 10 & 35 & & 22 \\
\hline $\mathrm{Ni}$ & - & - & 3 & - & 12 & - \\
\hline $\mathrm{As}$ & 6 & 1 & 9 & - & 18 & 3 \\
\hline $\mathrm{Pb}$ & - & - & - & 47 & - & - \\
\hline $\mathrm{Cu}$ & 551 & 1045 & 93 & 122 & 56 & 14 \\
\hline $\mathrm{W}$ & 28 & 27 & & 4636 & 123 & 42 \\
\hline $\mathrm{Au}$ & - & 31 & 36 & - & - & - \\
\hline $\mathrm{Ag}$ & - & - & - & - & - & 68 \\
\hline $\mathrm{Rb}$ & 10 & - & - & 17 & 78 & 275 \\
\hline $\mathrm{Nb}$ & - & - & 107 & 49 & 22409 & 211 \\
\hline $\mathrm{Cd}$ & - & - & 27 & - & 295 & 171 \\
\hline $\mathrm{Sn}$ & 364 & 249 & 56 & 7082 & 17645 & 452 \\
\hline $\mathrm{Ta}$ & - & - & - & - & 10935 & 128 \\
\hline $\mathrm{Fe}$ & 1691 & 15162 & 2532 & 21900 & 1354 & 2922 \\
\hline $\mathrm{U}$ & - & - & - & - & 22 & 4 \\
\hline
\end{tabular}

Table-6: Trace Element concentration in Soil samples within the Kaiama area

\begin{tabular}{|c|c|c|c|c|c|c|c|}
\hline \begin{tabular}{|l|} 
Location \\
Element
\end{tabular} & MP1 & MP3 & MP6 & MP8 & MP9 & MP11 & MP13 \\
\hline $\mathrm{S}$ & 217 & 530 & 454 & 646 & 674 & 162 & 351 \\
\hline $\mathrm{Ti}$ & 2168 & 594 & 25999 & 2104 & 1595 & 1095 & 25900 \\
\hline $\mathrm{V}$ & 14 & & 46 & & 23 & 48 & 76 \\
\hline $\mathrm{Zn}$ & 273 & 63 & 76 & 73 & 170 & 24 & 47 \\
\hline $\mathrm{Cr}$ & - & 47 & & 20 & 499 & 80 & - \\
\hline Co & 48 & - & 705 & 18 & 34 & 1827 & 642 \\
\hline $\mathrm{Ni}$ & 188 & - & 16 & 113 & 94 & 16 & 25 \\
\hline As & 4 & - & - & - & - & - & - \\
\hline $\mathrm{Pb}$ & 56 & - & - & - & 164 & 29 & 12 \\
\hline $\mathrm{Cu}$ & 170 & 15 & 35 & 1305 & 1002 & 14 & 21 \\
\hline $\mathrm{W}$ & 21716 & 0 & 22 & 136 & 1000 & 106 & 58 \\
\hline $\mathrm{Au}$ & 8452 & 0 & - & 84 & 300 & - & 17 \\
\hline $\mathrm{Ag}$ & 5 & 0 & 9 & 67 & 30 & - & 4 \\
\hline $\mathrm{Rb}$ & 2 & 12 & 1 & 7 & 195 & 1 & $<1$ \\
\hline $\mathrm{Ta}$ & 127 & - & - & 6885 & 4593 & - & \\
\hline $\mathrm{Nb}$ & 11 & 0 & 79 & 2574 & 1980 & 4 & 95 \\
\hline Mo & 218 & 0 & 347 & 146 & 177 & 208 & 254 \\
\hline $\mathrm{Cd}$ & 1 & 112 & - & 151 & 192 & - & - \\
\hline Sn & 39523 & 230 & 236 & 50252 & 14213 & 522 & 516 \\
\hline $\mathrm{Sb}$ & 239 & & 113 & 229 & 191 & 178 & 508 \\
\hline $\mathrm{Fe}$ & 10103 & 2288 & 31282 & 3234 & 7698 & 62838 & 3394 \\
\hline $\mathrm{Zr}$ & 0 & 74 & 0 & 0 & 0 & 0 & 0 \\
\hline
\end{tabular}


Table-7: Trace Element concentration in Stream sediment samples within the Kaiama area

\begin{tabular}{|l|l|l|l|l|l|}
\cline { 1 - 5 } Location & & & & & \\
\cline { 1 - 4 } Element & MP2 & MP4 & MP5 & MP7 & MP12 \\
\hline $\mathrm{S}$ & 382 & 498 & 345 & 726 & 194 \\
\hline $\mathrm{Ti}$ & 338243 & 1340 & 27730 & 5572 & 371 \\
\hline $\mathrm{V}$ & 320 & 153 & 106 & 40 & 15 \\
\hline $\mathrm{Zn}$ & 50 & 72 & 54 & 71 & 63 \\
\hline $\mathrm{Cr}$ & - & - & - & - & 20 \\
\hline $\mathrm{Co}$ & 967 & 852 & 692 & 81 & 444 \\
\hline $\mathrm{Ni}$ & 25 & 63 & 26 & 54 & 45 \\
\hline $\mathrm{Cu}$ & 19 & - & 19 & 439 & 24 \\
\hline $\mathrm{W}$ & 144 & 2153 & 114 & - & 029 \\
\hline $\mathrm{Au}$ & - & 554 & - & 164 & - \\
\hline $\mathrm{Ag}$ & 1 & - & 6 & 5 & 3 \\
\hline $\mathrm{Rb}$ & - & - & - & - & $<1$ \\
\hline $\mathrm{Nb}$ & 33 & 99 & 99 & 790 & 3 \\
\hline $\mathrm{Mo}$ & 202 & 238 & 238 & 196 & 204 \\
\hline $\mathrm{Sn}$ & 1327 & 605 & 605 & 451 & 758 \\
\hline $\mathrm{Sb}$ & 146 & 181 & 180 & 96 & 508 \\
\hline $\mathrm{Fe}$ & 40603 & 40603 & 30373 & 13176 & 21234 \\
\hline
\end{tabular}

Table-8: Table Comparing Average Abundance of Trace Elements in the earth continental crust and granites

\begin{tabular}{|l|l|l|l|l|l|l|l|l|}
\hline Elements & Crust & Granites & veins & soil & Stream sed & SD Vein & SD Soil & SD Str Sedmnt \\
\hline $\mathrm{S}$ & 4400 & 1500 & 187.8 & 433.4 & 429.0 & 344.4 & 200.0 & 198.4 \\
\hline $\mathrm{Ti}$ & 260 & 58 & 34.50 & 8493 & 74615 & 42.23 & 11937 & 147771 \\
\hline $\mathrm{Nb}$ & 20 & 24 & 37.96 & 677.5 & 204.80 & 9118 & 1106 & 392.8 \\
\hline $\mathrm{Sn}$ & 2 & 3.5 & 4308 & 15070 & 749.2 & 7078 & 21213 & 340.7 \\
\hline $\mathrm{W}$ & 1.5 & 0.4 & 809 & 3291 & 488.0 & 1875 & 8132 & 932.6 \\
\hline $\mathrm{Cu}$ & 55 & 13 & 313.5 & 366.0 & 100.0 & 408.1 & 547.7 & 189.6 \\
\hline $\mathrm{Pb}$ & 13 & 48 & 7.833 & 3728 & 0.4 & 19.18 & 56.56 & 0.894 \\
\hline $\mathrm{Co}$ & 25 & 2.4 & - & 467.7 & 607.2 & 1 & 673.2 & 353.5 \\
\hline $\mathrm{Au}$ & 1.8 & 0.5 & 6.166 & 0.571 & 143.6 & 17.37 & 3171 & 240.1 \\
\hline $\mathrm{Zn}$ & 70 & 45 & 12.16 & 103.7 & 62.00 & 19.88 & 87.55 & 9.874 \\
\hline $\mathrm{Ni}$ & 75 & 1 & 2.500 & 64.57 & 42.60 & 4.808 & 69.40 & 16.86 \\
\hline $\mathrm{Rb}$ & 90 & 220 & 63.30 & 31.25 & 0.180 & 107.7 & 72.35 & 0.402 \\
\hline $\mathrm{Cr}$ & 100 & 20 & 28.00 & 92.28 & 4.000 & 16.25 & 181.8 & 8.944 \\
\hline $\mathrm{V}$ & 135 & 17 & 14.50 & 29.57 & 126.8 & 0.516 & 28.28 & 120.9 \\
\hline $\mathrm{Cd}$ & 0.2 & 0.03 & 82.17 & 65.14 & - & 123.68 & 84.17 & - \\
\hline $\mathrm{Ag}$ & 0.07 & 0.05 & 11.33 & 16.3 & 3.00 & 27.76 & 24.57 & 2.55 \\
\hline $\mathrm{Ta}$ & 2 & 1.5 & 1843.83 & - & - & 4454.04 & - & - \\
\hline $\mathrm{Sb}$ & 0.2 & 0.31 & - & 208.29 & 222.2 & - & 155.39 & 163.47 \\
\hline
\end{tabular}

\section{CONCLUSION}

The integrated reconnaissance geological and geochemical survey has been undertaken in Kaiama and environs. Geological mapping of the area has revealed that Kaiama and environs is underlain by granite, migmatite, schist, and amphibolite. The pegmatite and quartz vein in the studied area showed indications of mineralization. Satellite imagery were used to recognise areas with alteration signifying mineralization, sampling for geochemical analysis have been subjected to these areas via soil, vein, and stream.

Further exploration work should be concentrated on soils and stream sediments towards delineating the possible ore deposit in the area of Kaiama and environs.

\section{REFERENCES}

1. Runge. (1996). Mining Economics and Strategy. Edited by Andrew Mular, Doug Halbe and Derek Barratt, Society for Mining and Metallurgy and Exploration Inc. (SME), Littleton U.S.A, New York, U.S.A

2. Vogley, A.W.(1985). Economic of Mineral Industries. American institute of mining, Metallurgical and petroleum engineers, Inc., New York, U.S.A

3. Ajaka, E. O., \& Oyathelemi, E. O. (2010). Suggesting area for detailed investigation of mineral occurrence in Nigeria for National Resource Database. ARPN Journal of Engineering and Applied Sciences, 5(11), 27-39. 
4. Jacobson, R., \& Webb, S. (1946). The Pegmatites of Central Nigeria. Geological Survey Bulletin, 17, 1-73.

5. Aikawa, M., Iseki, M., Barnwell, J. W., Taylor, D., Oo, M. M., \& Howard, R. J. (1990). The pathology of human cerebral malaria. The American journal of tropical medicine and hygiene, 43(2_Part_2), 30-37.

6. Matheis, G., \& W.O. Emofurieta, (1987): Nigerian Rare metal pegmatites and their lithological framework". J. Geol., 22: 271-291.

7. Matheis, G., \& V. Caen. (1983). "Rb-Sr isotopic study of rare metal bearing and barren pegmatites in the Pan-African reactivation zone of Nigeria". Journal of Africa Earth Sciences, 1: 35-40.

8. Adekeye, J. I. D. (1999). Heavy Minerals in Stream Sediments and their Relationship to Bedrock types and mineralization in Oro area southwestern Nigeria. Nigeria, J.pure and applied science, 14: 906-914.

9. Adekoya, J.A. (1993). Preterozoic Maru and Birnin -Gwari banded iron formations, Northwestrn Nigeria. J. Min. Geol, 29(1): 63-76.

10. Olobaniyi, S.B. (1997). Geological and geochemical studies of the basement rocks and associated iron formation of Isanlu area in EgbeIsanlu schist belt, southwestern Nigeria.Unpublished Ph.D. thesis, University of Ilorin, Nigeria, 262.

11. Jacques, E.H. (1947). Geology of Egbe district, Kabba Province Geological Survey of Nigeria. Unpublished Annual Reports. No 715

12. Akande, S.O., Fakorede, O., \& Mucke, A. (1988). Geology and genesis of gold bearing quartz veins at Birnin Yauri and Okolom in the Pan African domain of western Nigeria. Geol. En Mijbro, 67: 41-51.

13. Garba. (1988). Tourmalinazation related to late Proterozoic-early Paleozoic Lode Gold mineralization in Yauri area, Nigeria. Mineralium Deposita, 31(3), pp 201-209.

14. Durotoye, M.A., \& Ige, O.A. (1991). An inventory of talc deposits in Nigeria and their industrial application potentials. Journal of mining and Geology, 19, 23-25

15. Akin-Ojo, O.A. (1992). Compositional and indusrial studies of talc bodies in the Precambrian domain of South-Western Nigeria. Unpublished Ph.D Thesis, University of Ibadan.

16. Bafor B.E. (1981). The Occurrence of Sulphide mineralization in the Egbe area of South Western Nigeria. J. Min. Geol, 18(1), 175-197.

17. Bafor B.E. (1988). Some geological consideration in the evolution of the Nigeria basement in the Nigerian in: Oluyide, W.C. Mbonu, A.E. Ogezi, I.G. Egbnniwe, AC. Ajibade and A.C. Umeji (eds) Precambrian geology of Nigeria. Geol. Surv. Of Nigeria, 277-288.

18. Woakes, M,. \& Bafor, B.E. (1984). Primary gold mineralization in Nigeria. In Proc. Symp. On
Gold, Zimbabwe '82, A.A. Balkema, Rotterdam, (Foster, R. Ed.), 661-667.

19. Adekeye, J. I. D., \& Adedoyin, A. D. (2007). Economic potentials of the pegmatites of Eruku area, southwestern Nigeria .Department of Geology and Mineral Sciences, University of Ilorin, Nigeria. Continental J. Earth Sciences 2: 16, 2007

20. Obaje N.G. (2009). Geology and Mineral resources of Nigeria, Springer, Heidelberg, 13-31.

21. Oyinloye, A. O. (2011). Geology and geotectonic setting of the basement complex rocks in South Western Nigeria: implications on provenance and evolution. In Earth and Environmental Sciences. InTech.

22. Kayode, J. S., Nawawi, M. N. M., Abdullah, K. B., \& Khalil, A. E. (2017). Integrating aeromagnetic and Landsat ${ }^{\mathrm{TM}} 8$ data into subsurface structural mapping of Precambrian basement complex. Journal of African Earth Sciences, 125, 202-213.

23. Aliyu, A. S., Musa, Y., Liman, M. S., Abba, H. T., Chaanda, M. S., Ngene, N. C., \& Garba, N. N. (2018). Determination of rare earth elements concentration at different depth profile of Precambrian pegmatites using instrumental neutron activation analysis. Applied Radiation and Isotopes, 131, 36-40.

24. Ogezi, A.E.O. (1977). Geochemistry and Geochronology of Basement Rocks from Northwestern Nigeria. Unpublished Ph.D. Thesis, University of Leeds.

25. Rahaman, M.A. (1988). Recent advances in the study of the basement complex of Nigeria. In: Geological Survey of Nigeria (ed) Precambrian Geology of Nigeria, 11-43.

26. Olade, M,A., \& Elueze, A.A. (1979). Petrochemistry of the Ilesha amphibolite and Precambrian crustal evolution in the Pan-African domain of SW Nigeria. Precambrian Res, 8:303318.

27. Egbuniwe, I.G. (1982). Geotectonic evolution of the Maru Belt, NW Nigeria. Unpublished Ph.D. Thesis, University of Wales, Aberystwyth.

28. McCurry, P. (1976). The Geology of the Precambrian to Lower Paleozoic rocks of Northern Nigerian, a Review in C.A., Kogbe (Ed.), Lagos, Elizabethan Publishing Co. Geology of Nigeria, 15-39.

29. Rahaman, M. A. (1976). Review of the basement complex of Nigeria in: Kogbe, C. A. (ed) Geology of Nigeria. Elizabethan publishing Lagos, Nigeria, 514.

30. Grant, N.K. (1978). Structural distinction between a metasedimentary cover and an underlying basement in the 600 m.y old Pan-African domain of Northwestern Nigeria. Geological Society of America Bulletine, 89: 50-58.

31. Garba, I. (2000): Origin of Pan-African mesothermal gold mineralization of Bin Yauri, 
Nigeria. Journal of African Earth Sciences, 31(2): 433-449.

32. Danbatta, U.A. (2003). Structural framework underlying the metamorphic evolution of the Kazuare Schist Belt, NW Nigeria. Global Journal of Geological Sciences, 1(1): 82-83.

33. Oluyide, P.O. (1988). Structural Trends in the Nigerian Basement Complex. In: P.O. Oluyide. Precambrian Geology of Nigeria. Geological. Survey of Nigeria, 93-98.

34. Oluyide, P. O., \& Udoh, A. N. (1989). Preliminary comments on the fracture systems of Nigeria. In Proceedings of the National Seminar on earthquakes in Nigeria (Ed.) Ajakaiye D. E; Ojo S. B. and Daniyan M. A, 97-109.

35. Ajibade, A.C. (1980). Geotectonic evolution of the Zungeru Region, Nigeria. Unpublished Ph.D. Thesis, University of Wales, Aberystwyth.

36. Danbatta, U.A. (2002). Rb-Sr Isochron Dating of Granitoids from the Kazaure Schist Belts, NW Nigeria. Global journal of Pure and Applied sciences, 8(3): $319-322$.
37. Kelly, K.D., Hudson, T. (2007). Natural versus anthropogenic dispersion of metals to the environment in the Wulik River area, western Brooks Range, northern Alaska. Geochem: Explor. Environ. Anal, 87-96.

38. Salminen, A., Lehtonen, M., Suuronen, T., Kaarniranta, K., \& Huuskonen, J. (2008). Terpenoids: natural inhibitors of $\mathrm{NF}-\kappa \mathrm{B}$ signaling with anti-inflammatory and anticancer potential. Cellular and Molecular Life Sciences, 65(19), 2979-2999.

39. Crosta, A., and Moore, J., (1989). McM, Enhancement of Landsat Thematic Mapper imagery for residual soil mapping in SW Minais Gerais State, Brazil: a prospecting case history in Greenstone belt terrain. In Proceedings of the 7th ERIM Thematic Conference: Remote sensing for exploration geology, 1173-1187.

40. Mucke, A., \& Annor, A. (1993). Examplesand genetic significance of the formation of iron Oxides in the Nigerian banded iron formation. Mineral deposita, 28: 126-145. 